Kohut I, Marynych V, Chebanova K. Modern approaches to classification of karatekas with locomotorium disorders. Theory and Methods of Physical education and sports. 2019; 1: 9-15 DOI:10.32652/ tmfvs.2019.1.9-15
Когут І, Маринич В, Чебанова К. Сучасні підходи до класифікації спортсменів з порушниками опорно-рухового апарату в карате

Теорія і методика фрізичного виховання і спорту. 2019; 1: 9-15 DOI:10.32652/tmfvs.2019.1.9-15

\title{
СУЧАСНІ ПІДХОДИ ДО КЛАСИФІКАЦІЇ СПОРТСМЕНІВ З ПОРУШЕННЯМИ ОПОРНО-РУХОВОГО АПАРАТУ В КАРАТЕ
}

\section{Ірина Когут, Вікторія Маринич, Катерина Чебанова}

Національний університет фізичного виховання і спорту України, Київ, Україна

Анотація. Охарактеризовано види класифікацій спортсменів з порушенням опорно-рухового апарату в адаптивному спорті загалом та проаналізовано класи спортсменів з інвалідністю у карате WKF ma JKS. Проведено аналіз програмно-нормативних документів, що стосуються карате, науково-методичної та спеціальної літератури з питань класиорікації спортсменів Міжнародного паралімпійського комітету та міжнародних спортивних фредерацій осіб з інвалідністю. Мета. Виявлення особливостей класифрікації спортсменів з порушенням опорнорухового апарату, які займаються карате та беруть участь у змаганнях за різними версіями, а caмe World Karate Federation (WKF) ma Japan Karate Shoto Federation (JKS). Методи. Аналіз і узагальнення науково-методичної та спеціальної літератури. Результати. На сьогодні в адаптивному спорті класифрікація спортсменів з інвалідністю здійснюється відповідно до принципу рівності, забезпечуючи усім рівні можливості, необхідні для досягнення найвищого спортивного результату. Вона передбачає розподіл спортсменів за типом захворювання та за фуункиональними можливостями. Виділяють три види класифікації: медичну, функціональну та гандикапну. У ході аналізу програми змагань з карате було визначено, що класифрікація спортсменів за правилами WKF здійснюється за трьома категоріями для спортсменів, які змагаються в ката. А саме, спортсмени, які використовують візок, спортсмени з вадами зору та спортсмени, які мають інтелектуальні порушення. За правилами JKS, класифрікація спортсменів представлена такими групами: спортсмени з ампутаціями (три групи), спортсмени з наслідками церебрального паралічу, спортсмени з відхиленнями розумового розвитку та спортсмени, які пересуваються на візках. В карате, як і в інших видах спорту, використовуються фрункціональні класифрікації, які спираються на загальноприйняту медичну. Сьогодні існують дві принципово різні фуннціональні класифрікації спортсменів в карате, які беруть участь в окремих змаганнях. Система класифікації WKF є більш об'ємною за рахунок збільшення кількості класів та суттєво відрізняється від системи класифрікації JKS.

Ключові слова: класифрікація, опорно-руховий апарат, нозологія, карате, спортсмен з інвалідністю.

\section{Iryna Kohut, Viktoriia Marynych, Kateryna Chebanova MODERN APPROACHES TO CLASSIFICATION OF KARATEKAS WITH LOCOMOTORIUM DISORDERS}

Abstract. Types of classification of athletes with locomotorium disorders in adaptive sports in general have been characterized and classes of sportsmen with disabilities in karate WKF and JKS have been analyzed. The analysis of program and normative documents related to karate, scientific-methodical and special literature on classification of athletes of the International Paralympic Committee and international sports federations of persons with disabilities was conducted. Objective. Identification of the characteristics of the classification of athletes with locomotor disorders involved in karate and participating in competitions in various versions, namely the World Karate Federation (WKF) and the Japan Karate Shoto Federation (JKS). Methods. Analysis and generalization of scientific-methodical and special literature. Results. Today, in adaptive sport, the classification of athletes with disabilities is carried out in accordance with the principle of equality, providing all the equal opportunities necessary to achieve the highest sports result. It involves the distribution of athletes by type of disease and functionality. There are three types of classification: medical, functional and handicap. In the analysis of the karate competition program, it was determined that the classification of athletes according to WKF rules is carried out in three categories for athletes who compete in kata. Namely, athletes using a wheel, athletes with visual impairments, and athletes with intellectual disabilities. According to the JKS rules, the classification of athletes is represented by the following groups: athletes with amputations (three groups), athletes with the consequences of cerebral palsy, athletes with mental disabilities, and athletes moving on wheels. In karate, as in other sports events, functional classifications are used that are based on the generally accepted medical. Today, there are two fundamentally different functional classifications of athletes in karate who take part in individual competitions. The WKF classification system is more voluminous at the expense of increasing the number of classes and is significantly different from the JKS classification system.

Keywords: classification, locomotorium, nosology, karate, disabled athlete.

Вступ. Класифікація спортсменів 3 інвалідністю має важливе значення в адаптивному спорті, зокрема в карате. В Україні існують класифікаційні норми та вимоги Єдиної спортивної кла- сифікації з видів спорту для людей з ураженнями опорно-рухового апарату, вадами зору, слуху та відхиленнями розумового і фізичного розвитку [13]. В них карате представлене тільки серед ви- 
дів спорту для спортсменів з вадами слуху, тоді як для осіб з ураженням опорно-рухового апарату та відхиленнями розумового розвитку класифікаційних вимог не існує. Це зумовлено тим, що класифікація спортсменів з інвалідністю в карате на міжнародному рівні має складну специфічну систему, яка до сьогодні не унормована на національному рівні. В світовому пара-карате існують два типи класифікацій для спортсменів з порушенням опорно-рухового апарату залежно від представництва федерації (версії) карате. Перша неофіційна класифікація була представлена федерацією Japan Karate Shoto Federation (JKS) на початку XXI ст.

Сьогодні карате для людей 3 інвалідністю вже розвивається і популяризується федерацією World Karate Federation (WKF), яка є офіційною та визнаною Міжнародним олімпійським комітетом (МОК). 32016 р. його включено до програми Ігор XXXII Олімпіади в Токіо (Японія), що привело до зміни в правилах змагань з пара-карате та появи нової системи класифікації спортсменів для включення в програму Паралімпійських ігор. Зі сказаного випливає, що поява нової системи класифікації спортсменів з інвалідністю потребує детального вивчення для впровадження в практику карате на національному рівні.

Для того, щоб забезпечити справедливі змагання між спортсменами, які мають різні порушення і відхилення, в карате, як і в інших видах спорту, розроблено порядок розподілу учасників на класи за їх функціональними можливостями, що передбачає визначення рівня збереження їхніх рухових можливостей. Функціональна класифікація грунтується на розподілі спортсменів на групи з урахуванням тих здібностей, які дозволяють їм змагатися в певній спортивній дисципліні [7]. Це означає, що спортсмени, які належать до різних нозологічних груп та мають різні медичні діагнози, можуть опинитися в одному функціональному класі, оскільки вони мають однакові (або схожі) функціональні можливості. Спортивний клас, до якого зараховують спортсменів, може з часом змінюватися залежно від того, покращився або погіршився їхній функціональний стан. Так, у кожного спортсмена, який прибув на змагання 3 карате, перевіряють класифікаційні документи, і тих осіб, які потребують перекласифікації, запрошують на комісію, де міжнародні фахівці (класифікатори) або підтверджують наявний клас або присвоюють новий [4].

Необхідно зауважити, що класифікація в паракарате має свою специфіку. На відміну від популярних паралімпійських видів спорту, де спортсменів розподіляють на класи на основі медичної та функціональної класифікації, в карате система розподілу залежить від версії змагань. Отже, програма змагань, правила суддівства та категорії спортсменів мають свої особливості у кожному конкретному випадку.
У роботах вітчизняних та зарубіжних фахівців сфери фізичної культури і спорту розкрито окремі аспекти, які стосуються класифікацій спортсменів. Зокрема, А. В. Передерій, М. С. Розторгуй вивчали паралімпійську класифікацію як лімітуючий фактор досягнення спортивного результату (на прикладі легкої атлетики) [14]; Г. М. Бойко, О. М. Максимова розглядали медико-психологічну класифікацію спортсменів 3 інвалідністю різних нозологічних груп [2]; Ю. А. Бріскін, А. В. Передерій торкалися питань детермінуючих чинників та напрямів удосконалення класифікації у паралімпійському пауерліфтингу [3]; М. С. Розторгуй, А. В. Передерій займалися вивченням алгоритму системи класифікації у паралімпійському пауерліфтингу [15]. Крім цього, є дослідження, присвячені психологічній класифікації спортсменів 3 відхиленнями розумового та фізичного розвитку [1], класифікації в паралімпійському спорті за допомогою гандикапу [14]. Проте, необхідно зазначити, що відсутні дослідження, присвячені класифікації спортсменів з інвалідністю в карате, що й зумовлює актуальність представленої наукової теми.

Роботу виконано в рамках теми 1.7. «Організаційно-методичні основи розвитку адаптивного спорту» плану науково-дослідної роботи НУФВСУ на 2016-2020 рр. (номер держреєстрації 0116U001613).

Мета дослідження - виявлення специфіки класифікації спортсменів з порушеннями опорнорухового апарату в карате.

Методи дослідження: аналіз і узагальнення науково-методичної та спеціальної літератури, програмно-нормативних документів, що стосуються карате, аналіз документальних джерел.

Результати дослідження та їх обговорення. Розглядаючи питання класифікації спортсменів 3 інвалідністю, перш за все необхідно проаналізувати зміст терміна «класифікація», який має неоднозначне визначення у роботах різних науковців [5, 9]. В енциклопедичній літературі цей термін визначено як логічну операцію, яка полягає в поділі всього досліджуваного (предметів або явищ) за виявленими подібностями і відмінностями на окремі групи, або класи, а також як систему понять (класів, об'єктів) будь-якої галузі знань чи діяльності людини. У першому випадку класифікація - це процес, метод дослідження, у другому - результат (продукт класифікації) [16]. Під класифікацією спортсменів в адаптивному спорті мають на увазі безпосередній процес розподілу спортсменів на ті чи інші групи, класи, дивізіони і власне його результат, тобто яким чином та за якими критеріями (насамперед юридично) відбувався розподіл на групи, класи, дивізіони [12].

Складні об'єкти і явища дійсності, структура яких різноманітна, зазвичай не можуть бути класифіковані за допомогою однієї класифікаційної ознаки. Саме таким складним об'єктом є спорт- 
смени, які займаються адаптивним спортом. Розподілити їх на групи, класи, дивізіони, виходячи з однієї класифікаційної ознаки, неможливо. До класифікаційних ознак належать: стать, вік, вага, наявність і тяжкість ураження або наявність залишкових функціональних можливостей тощо. У цьому випадку використовують складні варіанти поділу, що включають кілька ознак [5, 12].

Важливо підкреслити, що використання класифікаційних ознак реалізує найважливіший принцип класифікації - забезпечення рівних можливостей у досягненні спортивного результату, який передбачає максимально можливе зрівняння шансів спортсменів на перемогу в межах стартової групи (принцип справедливості) [3, 4, 14].

На сьогодні в адаптивному спорті виділяють три види класифікації: медична, функціональна, гандикапна [4, 5, 14].

За медичною класифікацією розподіл спортсменів на класи дає можливість участі в змаганнях 3 конкретного виду адаптивного спорту. Класифікацію спортсменів здійснюють за медичними критеріями без урахування специфіки спортивної діяльності [2, 8].

В адаптивному спорті також використовують інший вид класифікації - функціональний, що передбачає розподіл спортсменів на класи, виходячи 3 особливостей конкретного виду спорту, специфіки їх змагальної діяльності та функціональних можливостей з урахуванням попередньої медичної класифікації [5, 7].

На думку деяких учених, медичну і функціональну класифікацію, які використовують в адаптивному спорті, доречно порівняти 3 двома видами класифікацій станів людини, розроблених Всесвітньою організацією охорони здоров’я. Це Міжнародна статистична класифікація хвороб i проблем, пов'язаних зі здоров'ям (Міжнародна класифікація хвороб 10-го перегляду, МКХ-10), яка визначає етіологічну структуру хвороб (хвороба, розлад, травма), і Міжнародна класифікація функціонування, обмежень життєдіяльності та здоров'я (Міжнародна класифікація функціонування, МКФ), що дає характеристику функціонування і обмежень життєдіяльності, пов'язаних зі змінами здоров'я [6].

Гандикапна класифікація передбачає присвоєння певному функціональному класу коефіцієнта, що впливає на реальний результат спортсменів. Використання гандикапної класифікації дозволяє об'єднати в межах однієї стартової групи спортсменів різних функціональних класів. Таке об'єднання здійснюють для підвищення конкуренції (як це робиться в зимових паралімпійських видах лижного і гірськолижного спорту, в яких виділяють всього три стартові групи: спортсмени, які змагаються стоячи, сидячи та незрячі спортсмени), або за недостатньої кількості спортсменів одного спортивного функціонального класу для формування мінімальної, заданої правилами змагань, кількості спортсменів у стартовій групі [14].

Порядок, процедура й умови класифікації спортсменів за ступенем їхніх функціональних можливостей, заявлених для участі у змаганнях, вказуються в правилах змагань та мають бути сформульовані відповідно до вимог Міжнародного паралімпійського комітету (МПК) і міжнародних спортивних федерацій осіб з інвалідністю [19].

Кількість класів спортсменів для участі в змаганнях у кожному виді спорту визначається комітетом (комісією) з цього виду спорту національного паралімпійського комітету та відповідною федерацією з виду спорту на основі рішення МПК або міжнародних спортивних федерацій осіб 3 інвалідністю. Зміна кількості класів може здійснюватися на підставі змін (збільшення або зменшення) функціональних відмінностей спортсменів, виявлених у ході змагань, а також змін кількості спортсменів у межах одного класу. Відповідно до класифікації ступінь функціональних можливостей визначається в кожному виді спорту окремо [19].

Аналізуючи програми змагань з карате, в яких беруть участь спортсмени з інвалідністю, та офіційні правила Всесвітньої федерації карате (World Karate Federation, WKF), було визначено важливі положення класифікації.

Класифікація спортсменів за правилами WKF здійснюється за трьома категоріями для спортсменів, які змагаються в ката [10, 20]:

- спортсмени, які використовують візок;

- спортсмени з вадами зору;

- спортсмени, які мають інтелектуальні порушення.

Система класифікації WKF полягає в тому, що спортсмени мають право на участь у змаганнях, якщо вони класифікуються відповідно до МКХ (табл. 1) і МКФ (табл. 2), що визнані стандартним діагностичним інструментом Всесвітньої організації охорони здоров'я на міжнародному рівні.

Безпосередньо під час змагань проводиться додаткове тестування призначеними експертами МКФ. Варто зазначити, що національний тренер повинен постійно перебувати зі спортсменами під час проходження комісії [11].

Для участі спортсменів у змаганнях національні федерації повинні включити в онлайн-систему реєстрації WKF медичні довідки спортсменів, а також перелік необхідних терапевтичних заходів, схвалених відповідною національною антидопінговою організацією [20].

Рівень інвалідності в кожній категорії помічено відповідними кольорами: червоним, жовтим, зеленим і синім (рис. 1).

Крім процедури класифікації спортсмени з інвалідністю в карате проходять процедуру перекласифікації. Офіційний класифікатор або лікар WKF може перекласифікувати спортсменів у ході змагань у будь-який час. У разі перекласифікації 
Таблиця 1 - Класифікація спортсменів з інвалідністю в карате WKF за MKX-10

\begin{tabular}{|c|c|c|}
\hline Категорія & Класифікація за МКХ-10: & \\
\hline \multirow{7}{*}{$\begin{array}{l}\text { Спортсмени, які викорис- } \\
\text { товують візок }\end{array}$} & S 14 & Травма спинного мозку на рівні шиї \\
\hline & S 24 & Травма спинного мозку на рівні грудної клітки \\
\hline & S 34 & $\begin{array}{l}\text { Травма поперекового відділу спинного мозку на рівні живота, нижньої } \\
\text { частини спини і таза }\end{array}$ \\
\hline & T 05 & Травматична ампутація кількох ділянок тіла \\
\hline & T 05.3 & Травматична ампутація обох стоп \\
\hline & T 05.4 & Травматична ампутація однієї стопи й іншої ноги \\
\hline & T 05.5 & Травматична ампутація обох ніг \\
\hline \multirow{8}{*}{$\begin{array}{l}\text { Спортсмени з вадами } \\
\text { зору }\end{array}$} & H 53 & Візуальні порушення \\
\hline & H 54 & Порушення зору, включаючи сліпоту (бінокулярну або монокулярну) \\
\hline & H 54.0 & Сліпота, бінокуляр (на обох очах) \\
\hline & H 54.1 & Тяжке порушення зору, бінокулярне \\
\hline & H 54.2 & Помірне порушення зору, бінокулярне \\
\hline & H 54.4 & Сліпота, монокуляр (на одному оці) \\
\hline & H 54.5 & Серйозне порушення зору, монокулярне \\
\hline & H 54.6 & Помірне порушення зору, монокулярне \\
\hline \multirow{6}{*}{$\begin{array}{l}\text { Спортсмени, які мають ін- } \\
\text { телектуальні порушення }\end{array}$} & F 70 & Незначне відхилення (IQ 50-69) \\
\hline & F 71 & Помірне відхилення (IQ 35-49) \\
\hline & F 81 & Розлад розвитку за академічними навичками \\
\hline & F 82 & Порушення розвитку моторної функції \\
\hline & F 90 & Гіперкінетичні розлади \\
\hline & Q 90 & Синдром Дауна \\
\hline
\end{tabular}

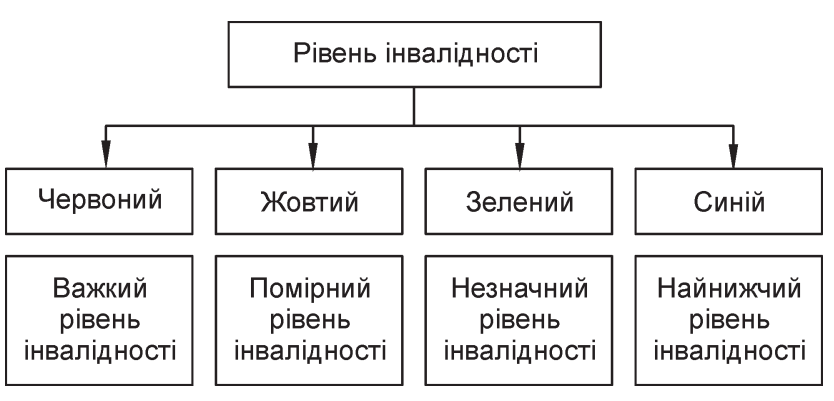

Рисунок 1 - Категорії рівнів інвалідності

спортсмена під час змагань через скарги або за рішенням класифікатора додаткові бали, отримані на змаганні, будуть додані до тих, які відповідають новій оцінці, виставленій офіційним класифікатором WKF. Якщо з'ясовується, що спортсмен навмисно сказав неправду класифікатору, він отримує дискваліфікацію [18, 20].

Виступи по ката в карате WKF оцінюються за допомогою точної системи балів. У змаганнях людей з інвалідністю існує система додаткових балів. Після класифікації ступеня інвалідності по МКХ, МКФ та додаткового розгляду до оцінки рефері додаються додаткові бали відповідно до ступеня інвалідності:

• червоний рівень: 3 бали;
- жовтий рівень: 2 бали;

- зелений рівень: 1 бал;

- синій рівень: 0 балів.

На татамі працюють сім суддів, які оцінюють ката з урахуванням двох критеріїв відповідно до системи очок: техніка виконання та оцінка демонстрації ката. Середній бал у першому колі - 7.0, у фіналі - 8.0. Під час розрахунку остаточного бала за виконання ката найвищий і найнижчий бали 3 двох оцінок не враховуються [20].

Окрім представленої класифікації спортсменів з інвалідністю в карате WKF існує інша система, яка використовується у змаганнях з карате за версією Japan Karate Shoto Federation (JKS).

Класифікація спортсменів в пара-карате за правилами JKS представлена такими групами: спортсмени з ампутаціями (3 групи), спортсмени 3 наслідками церебрального паралічу, спортсмени 3 відхиленнями розумового розвитку та спортсмени, які пересуваються на візках [17].

Класифікація спортсменів з ампутаціями включає:

\section{Г р у п а 1}

$\boldsymbol{K} \boldsymbol{л} \boldsymbol{a c} \boldsymbol{A 2 .}$ Одностороння ампутація стегна; одностороння ампутація стегна в поєднанні з ампутацією стопи іншої ноги по Пирогову; одностороння ампутація стегна в поєднанні з ампутацією стопи іншої ноги на різному рівні; одностороння ампута- 
Таблиця 2 - Класифікація спортсменів з інвалідністю в карате WKF за МКФ (версія МКФ 2005):

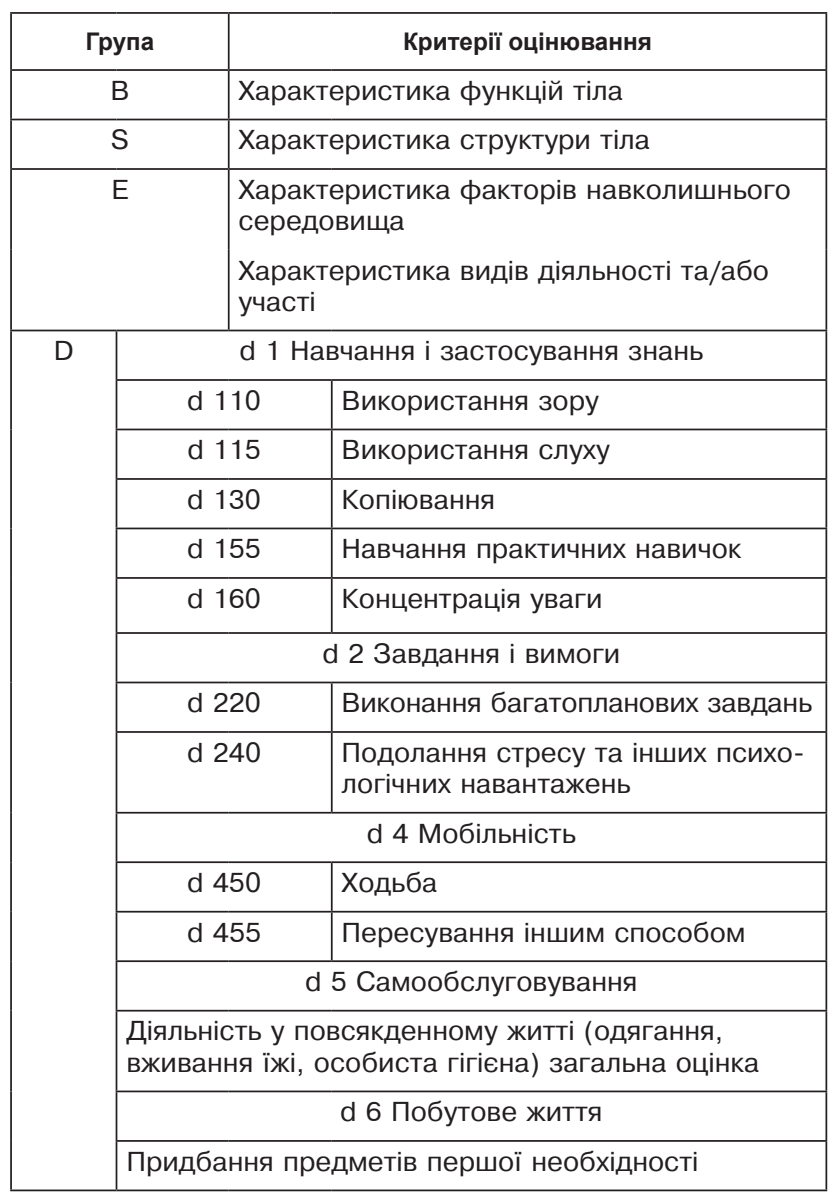

ція стегна в поєднанні 3 ампутацією гомілки іншої ноги.

Клас A4. Одностороння ампутація гомілки; одностороння ампутація гомілки в поєднанні з ампутацією стопи іншої ноги; двостороння ампутація стопи по Пирогову (хороша опора на п'яту). Мiнімальна фізична вада для допуску до змагань ампутація повинна проходити, принаймні, через надп’ятково-гомілковий суглоб.

\section{Г р у п а 2}

$\boldsymbol{\kappa} \boldsymbol{л \boldsymbol { a }} \boldsymbol{A \boldsymbol { 6 }}$. Одностороння ампутація плеча в поєднанні з ампутацією стопи по Пирогову; одностороння ампутація плеча в поєднанні з ампутацією стопи на різному рівні.

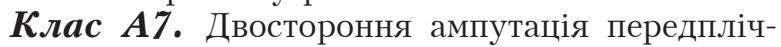
чя; ампутація передпліччя в поєднанні з ампутацією плеча з іншого боку.

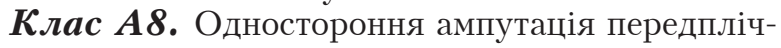
чя; мінімальна фізична вада - ампутація проходить по променево-зап'ястковому суглобі; ампутація передпліччя в поєднанні 3 ампутацією стопи по Пирогову й іншими ампутаційними дефектами стопи.

Г р у п а 3

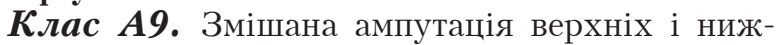
ніх кінцівок; одностороння ампутація передпліччя в поєднанні з односторонньою ампутацією стегна; ампутація плеча в поєднанні з ампутацією стегна; одностороння ампутація передпліччя в поєднанні 3 ампутацією гомілки.

Класифікація спортсменів з наслідками церебрального паралічу передбачає розподіл на два класи (С7 і С8).

C7. Спортсмен має мимовільні м'язові спазми 3 одного боку тіла. У нього є хороші функціональні можливості в домінуючій половині тіла. Він може ходити без сторонньої допомоги, але часто кульгає на одну ногу через мимовільні м'язові спазми. Під час бігу кульгавість може зникнути майже повністю. Домінуюча сторона тіла краще розвинена і добре виконує рухи під час ходьби і бігу. Кисть і рука вражені з одного боку тіла, а з іншого боку демонструється хороша рухливість руки.

C8. У спортсмена мінімальні мимовільні спазми однієї з рук, ніг або половини тіла. Щоб змагатися в даному класі, спортсмен повинен мати діагноз церебральний параліч або інше не прогресуюче ураження головного мозку.

Класифікація спортсменів з відхиленнями розумового розвитку передбачає існування лише однієї групи, до якої входять спортсмени з розумовими розладами, синдромом Дауна, неспроможністю навчатися, поведінковими розладами, які мають коефіцієнт розумових здібностей менше 75. Сьогодні, враховуючи широкий спектр уражень зазначеної групи спортсменів, продовжується робота над створенням нових систем класифікації для осіб з відхиленнями розумового розвитку.

Класифікація спортсменів, які пересуваються на візках, включає осіб з такими формами захворювань: тетраплегія, параплегія та поліомієліт. Вона залежить від того, які саме частини спинного мозку знаходяться нижче ураженої зони [17].

Диференційованими захворюваннями у спортсменів з інвалідністю в карате є:

- параліч шийного відділу хребта (С5-C8), внаслідок чого завжди відбувається ураження рук та ніг (тетраплегія);

- параліч грудного відділу хребта (ТН1-ТН2) 3 різною нестабільністю тулуба, але з нормальним функціонуванням рук (параплегія);

- параліч у поперековому відділі з відсутністю рухової активності у ногах, але достатнім контролем тулуба (L1-S2) (параплегія).

Залежно від спортивної дисципліни в карате існують 4-8 категорій спортсменів. Класифікують їх відповідно до конкретних вимог спортивної дисципліни.

\section{Висновки:}

1. Класифікація в адаптивному спорті відіграє важливу роль у системі змагань людей $з$ інвалідністю та грунтується на гуманістичних і моральноетичних засадах. Розподіл спортсменів на групи та класи забезпечує рівні можливості в досягненні спортивного результату. Сьогодні в адаптивному спорті існують три види класифікацій: медична, функціональна та гандикапна. 
2. У більшості видів спорту, що мають статус паралімпійських, розроблено власні функціональні класифікації, які спираються на загальноприйняту медичну класифікацію, котрі використовуються і в карате. Важливо зауважити, що в карате існують дві принципово різні класифікації спортсменів, які використовують в окремих змаганнях. Відносно нова система класифікації, створена WKF, суттєво відрізняється від системи класифікації JKS, оскільки за рахунок збільшення кількості класів є більш об'ємною.

Перспективи подальших досліджень у цьому напрямі полягатимуть у вивченні питання розподілу спортсменів на класи в карате, дослідженні сучасних підходів до характеристики класифікацій для людей 3 інвалідністю.

Конфлікт інтересів. Автори заявляють, що відсутній будь-який конфлікт інтересів.

\section{Література}

1. Бойко ГМ. Психологічна класифікація спортсменів з вадами розумового та фізичного розвитку. Педагогіка, психологія та мед.-біол. пробл. фріз. виховання і спорту. 2006; (5): 8-13.

2. Бойко ГМ, Максимова ОМ. Медико-психологічна класифікація спортсменів-інвалідів різних нозологічних груп. Світ медицини та біології. 2005; (9): 34-39.

3. Бріскін ЮА, Передерій АВ, Розторгуй МС. Детермінуючі чинники та напрями вдосконалення класифікації у паралімпійському пауерліфтингу. Теорія та методика фріз. виховання і спорту. 2008; (8): 30-35.

4. Бріскін ЮА, Передерій АВ, Розторгуй МС. Шляхи вдосконалення класифікації в паралімпійському пауерліфртингу. Теорія і методика фрізичного виховання і спорту. 2009; (1): 3-6.

5. Евсеев C, Аксенова О. Понятийный аппарат и классификация профессиональноориентированных видов двигательной деятельности в адаптивном спорте. Наука в олимпийском спорте. 2006; (1): 31-33.

6. Евсеев C, Евсеева О. Технологии физкультурно-спортивной деятельности в адаптивной физической культуре. Москва: Litres; 2017. 440 с.

7. Зотин ВВ, Мельничук АА. Классификация спортсменов в адаптивном спорте. Курганский гос. ун-т. 2014: 125-129.

8. Идрисова ГЗ. Функциональная классификация спортсменов-паралимпийцев в практике врача по спортивной медицине. Спортивная медицина: наука и практика. 2014; (4): 109-115.

9. Когут IO, Гончаренко $Є B$. Перспективи наукових досліджень у спорті людей із відхиленнями розумового розвитку. Теорія і методика фріз. виховання і спорту. 2011; (1): 19-23.

10. Когут IO, Маринич ВЛ, Чебанова КВ. Еволюція ката на візках від Атої Сенсея до Паралімпійських ігор. Зб. тез доп. Х Міжнар. конф. молодих вчених [Інтернет]. 2017 [цитовано 2019 Січень 30]; 208-211. Доступно: https://unisport. edu.ua/sites/default/files/konferencya/nufzsu\%20konferentsii/zbirnik_tez_2017_na_sajt.pdf

11. Когут IO, Маринич ВЛ, Чебанова КВ. Сутність підготовки тренера для роботи зі спортсменами з інвалідністю. Теорія і методика фріз. виховання і спорту. 2017; (3): 20-25.

12. Морозов ЮС. Актуальные проблемы паралимпийского спорта. Научные основы современного прогресса. 2017; 116-121.

13. Про затвердження Змін до деяких наказів Міністерства молоді та спорту України: Наказ Міністерства молоді та спорту України № 4739; 2016 Груд 29. Відомості Кабінету міністрів України. 2018.

14. Передерій $A B$, Розторгуй MC. Класифікація в паралімпійському спорті за допомогою гандикапу. Фізична активність, здоров'я і спорт. 2011; 1(3): 41-49.

15. Розторгуй MC, Передерій AB. Алгоритм системи класифікації у паралімпійському пауерліфтингу. Молода спорт. наука України. 2009; 1(13): 263-267.

16. Селіванова ОО. Сучасна лінгвістика: термінологічна енциклопедія (1290 термінів і понять). Полтава: Довкілля-К; 2006. 716 с.

17. Categories JKS Continental Para Cup [Internet]. Austria: sportdata GmbH \& Co KG; 2019 [updated 2018 September 15; cited 2019 January 30]. Available from: https://www.sportdata.org/karate

18. How Disabled Players are Classified in Para-Karate Competitions [Internet]. WKF-handicapped; 2018 [updated 2018 November 5; cited 2019 January 30]. Available from: http://www.wkf-handicapped.com/how-disabled-players-areclassified-in-para-karate-competitions/

19. Official website of the Paralympic Movement. Classification. [Internet]. Bonn, Germany: International Paralympic Committee (IPC); 2018 [updated 2018 June 6; cited 2019 January 30]. Available from: / https://www.paralympic.org/classification

20. Sport. Para-karate. Rules \& regulations - documentation [Internet]. Official Site WKF; 2019 [updated 2017 October 16; cited 2019 January 30]. Available from: https://www.wkf.net/para-karate_rules.php

\section{Literature}

1. Boyko HM. Psychological classification of athletes with intellectual and physical disabilities. Pedahohika, psykholohiia ta med.-biolohichni problem fizvykhovannia i sportu. 2006; (5): 8-13.

2. Boyko HM, Maksymova OM. Medico-psychological classification of disabled athletes of different nosologic groups. Svit medytsyny ta biolohii. 2005; (9): 34-39. 
3. Briskin IA, Perederii AV, Roztorhuy MS. Determining factors and directions of classification improvement in Paralympic powerlifting. Teoriia i metodyka fizvykhovannia i sportu. 2008; (8): 30-35.

4. Briskin IA, Perederii AV, Roztorhuy MS. Ways of classification improvement in Paralympic powerlifting. Teoriia i metodyka fizvykhovannia i sportu. 2009; (1): 3-6.

5. Yevseev S, Aksenova O. Conceptual framework and classification of professionally oriented motor activity types in adaptive sport. Nauka v olimpiyskom sporte. 2006; (1): 31-33.

6. Yevseev S, Yevseeva O. Technology of physical culture and sports activity in adaptive physical culture. Moscow: Litres; 2017. 440 p.

7. Zotin VV, Melnichuk AA. Athlete classification in adaptive sport. Kurgan State University. 2014: 125-129.

8. Idrisova GZ. Functional classification of Paralympic athletes in practice of sports medicine physician. Sportivnaya meditsina. 2014; (4): 109-115.

9. Kohut IO, Honcharenko IV. Prospects of studies of people with intellectual disabilities in sport. Teoriia i metodyka fizvykhovannia i sportu. 2011; (1): 19-23.

10. Kohut IO, Marynych VL, Chebanova KV. Evolution of kata on wheels from Atoia Sensei to Paralympic games. $\mathrm{X}$ Mizhnarodna konferentsiia molodykh vchenykh [Internet]. 2017 [cited 2019 January 30]; 208-211. Available: https://unisport. edu.ua/sites/default/files/konferencya/nufzsu\%20konferentsii/zbirnik_tez_2017_na_sajt.pdf

11. Kohut IO, Marynych VL, Chebanova KV. Essence of coach preparation for work with disabled athletes. Teoriia $\mathrm{i}$ metodyka fizvykhovannia i sportu. 2017; (3): 20-25.

12. Morozov IS. Actual issues of Paralympic sport. Scientific bases of modern progress. $2017 ; 116-121$.

13. On approval of Changes to some orders of the Ministry of youth and sport of Ukraine: Order of the Ministry of youth and sport of Ukraine № 4739; 2016 Dec 29. Vidomosti Kabinetu ministriv Ukrainy. 2018.

14. Perederii AV, Roztorhuy MS. Classification in Paralympic sport by means of handicap. Fizychna aktyvnist, zdorovia i sport. 2011; 1(3): 41-49.

15. Roztorhuy MS, Perederii AV. Algorithm of classification system in Paralympic powerlifting. Moloda sportyvna nauka Ukrainy. 2009; 1(13): 263-267.

16. Selivanova OO. Modern linguistics: terminological encyclopaedia (1290 terms and notions). Poltava: Dovkillia-K; 2006. $716 \mathrm{p}$.

17. Categories JKS Continental Para Cup [Internet]. Austria: sportdata GmbH \& Co KG; 2019 [updated 2018 September 15; cited 2019 January 30]. Available from: https://www.sportdata.org/karate

18. How Disabled Players are Classified in Para-Karate Competitions [Internet]. WKF-handicapped; 2018 [updated 2018 November 5; cited 2019 January 30]. Available from: http://www.wkf-handicapped.com/how-disabled-players-areclassified-in-para-karate-competitions/

19. Official website of the Paralympic Movement. Classification. [Internet]. Bonn, Germany: International Paralympic Committee (IPC); 2018 [updated 2018 June 6; cited 2019 January 30]. Available from: / https://www.paralympic.org/classification

20. Sport. Para-karate. Rules \& regulations - documentation [Internet]. Official Site WKF; 2019 [updated 2017 October 16; cited 2019 January 30]. Available from: https://www.wkf.net/para-karate_rules.php

Надійшла 22.10.2018

Інформація про авторів

Когут Ірина Олександрівна, https:orcid.org/0000-0002-8862-9545, kogut_irina@ukr.net

Маринич Вікторія Леонідівна https:orcid.org/0000-0003-2784-680X wikleon@ukr.net

Чебанова Катерина Вікторівна https:orcid.org/0000-0003-4601-2130, jkasniper@gmail.com

Національний університет фрізичного виховання і спорту України, 03150, Київ, вул. Фізкультури, 1.
Information about the authors

Kogut Iryna, https:orcid.org/0000-0002-8862-9545, kogut_irina@ukr.net.

Marynych Viktoriia https:orcid.org/0000-0003-2784-680X wikleon@ukr.net

Chebanova Kateryna https:orcid.org/0000-0003-4601-2130, jkasniper@gmail.com

National University of Ukraine on Physical Education and Sport, 03150, Kyiv, Fizkul'tury str., 1. 